УДК. 621.362

\title{
ИСПОЛЬЗОВАНИЯ АЛЬТЕРНАТИВНОЙ ЭНЕРГЕТИКИ ПРИ РЕНОВАЦИИ ЖИЛЬЯ
}

\author{
Шелехов Игорь Юрьевич \\ к.т.н., доцент кафедры ГСХ \\ Шелехов Максимилиан Игоревич \\ студент группы КНб-17-1 \\ Мартынов Сергей Никитович \\ магистранты группы ГСХм-19-1 \\ ФГБОУ ВО «ИРНИТУ»
}

Аннотация: В статье представлены результаты исследования системы теплый пол, работающей от солнечного коллектора. Для оптимизации работы системы используется дополнительный альтернативный источник энергии, созданный на основе термоэлектрических модулей. В статье показано, что применение термоэлектрических устройств в инженерных системах является перспективным направление научных исследований, которое открывает новые перспективы для проектирования автономных систем жизнеобеспечения. Авторы показали, что при применении новых технических решений можно обеспечить оптимальные параметры микроклимата в помещениях без использования традиционных источников энергии. Результаты исследований показали, что предложенные технические решения возможно применить при реновации старого жилья. При этом, появляется возможность по снижению эксплуатационных затрат, оптимизации энергетической нагрузки в инженерных сетях. Формирование знаний в данном направлении определит вектор развития новых технологий, применяемых в городском строительстве и в модернизации инженерных систем зданий.

Ключевые слова: Термоэлектрический генератор, инженерная система, теплый пол, солнечный коллектор, энергосбережение. 
THE USE OF ALTERNATIVE ENERGY IN HOUSING RENOVATION

\title{
Shelekhov Igor \\ Shelekhov Maximilian \\ Martynov Sergei
}

\begin{abstract}
The article presents the results of a study of the underfloor heating system powered by a solar collector. To optimize the operation of the system, an additional alternative energy source is used, created on the basis of thermoelectric modules. The article shows that the use of thermoelectric devices in engineering systems is a promising direction of scientific research, which opens up new prospects for the design of autonomous life support systems. The authors have shown that when applying new technical solutions, it is possible to provide optimal microclimate parameters in rooms without using traditional energy sources. The research results showed that the proposed technical solutions can be applied when renovating old housing. At the same time, it becomes possible to reduce operating costs, optimize the energy load in engineering networks. The formation of knowledge in this direction will determine the vector of development of new technologies used in urban construction and in the modernization of engineering systems of buildings.
\end{abstract}

Key words: Thermoelectric generator, engineering system, under floor heating, solar collector, energy saving.

Под словом реновация, мы обычно понимаем процесс сноса старого малоэтажного жилья и строительство на этом месте нового, многоэтажного. С экономической точки зрения, процесс реновации направлен на преобразование основного капитала, выраженного в материальном активе, в более привлекательное и экономически обоснованное предложение. Путем реконструкции помещения, его технического перевооружения, возможно, не только повысить его качественный уровень, но и изменить назначение.

Мировой опыт реновации в центральной части города показывает, что процесс замены одних зданий на другие, не снимает экономической и физической нагрузки на данный район. Любое изменение количества жителей в любом районе города, влечет за собой изменение инфраструктуры данного района. По мнению бывшего вице-губернатора Tokyo Metropolis, профессора Университета Мейдзи господина Ясуши Аояма, развитие крупных городов 


\section{МОЛОДЕЖНАЯ НАУКА КАК ФАКТОР И РЕСУРС

должно идти по пути децентрализации. Необходимо увеличивать качественные показатели административного и жилого фонда в центральных частях города, а многоэтажное строительство с прилагаемой инфраструктурой располагать ближе к окраинам [1].

Повышение качественных характеристик административного и жилого фонда, подразумевает использование дополнительных энергетических ресурсов. В подавляющем большинстве случаев, в центральных частях города, все возможности по использованию инженерных сетей исчерпаны. Поэтому, необходимо вести работы по применению «альтернативной энергетики» при осуществлении реновационных работ, которая совместно или раздельно с классическим источником энергии, будет использоваться для функционирования инженерных систем.

Одна из задач ученых, занимающихся альтернативной энергетикой, является эффективное использование возобновляемого ресурса. В данной статье, рассматривается энергетический ресурс в виде солнечной энергии, одновременно работающий с термоэлектрическим генератором. Самый простой и не дорогой способ использования энергии солнца, это нагрев воды, которую можно использовать для системы отопления и горячего водоснабжения [2].

На нагрев воды в инженерных системах тратится энергия, задача инженерной системы направить данную нагретую воду в то место, где она выполнит свою работу. Фактически, функционально, нагретой водой мы должны или нагреть помещение или использовать её для горячего водоснабжения. Кроме этого, солнце направляет нам свою энергию не круглосуточно, и даже в течение светового дня интенсивность солнечного излучения разная. Чтобы компенсировать данный дисбаланс в технологическом процессе, необходимо использовать аккумуляторы тепловой энергии. Чтобы эффективно использовать данную энергию, необходима система управления и исполнительные механизмы в виде клапанов и циркуляционных насосов [3]. По мнению многих ученых, в комплекте с солнечным коллектором целесообразней использовать систему теплый пол, применение которого способствует снижение энергопотребления на 10-25\%, при этом обеспечивается полноценный прогрев помещения, благодаря движению нагретых масс воздуха к потолку [4].

Анализ температурных режимов, присутствующих в инженерной системе теплый пол и в системе горячего водоснабжения, показывает, что при 


\section{МОЛОДЕЖНАЯ НАУКА КАК ФАКТОР И РЕСУРС \\ ОПЕРЕЖАЮЩЕГО РАЗВИТИЯ}

использовании совместно с данными системами термоэлектрических генераторов позволит получить необходимое количество энергии, необходимое для функционирования системы автоматики и исполнительных механизмов.

Анализ натурных исследований, представленных в работах показал, что для функционировании инженерных систем мощностью до 20 Квт, достаточна установка термоэлектрического генератора мощностью 200 Вт, фактически $1 \%$ энергии от установленной мощности системы достаточно для того, чтобы эта система была управляема, без привлечения дополнительного источника энергии $[5,6]$.

Для подтверждения наших расчетов, были проведены натурные исследования в здании частного дома с кирпичными стенами общей площадью 87 м². На крыше здания, под углом 35 градусов, были установлены два солнечных вакуумных коллектора общей площадью $20 \mathrm{~m}^{2}$ с баком аккумулятором на 150л.

Эксплуатация здания в течение одного зимнего месяца показала, что общее потребление автоматики и исполнительных механизмов составляет 600 Вт, средняя суточная наработка составляет не более 4 часов, соответственно суточное потребление электрической энергии не превышает значения 2400 Вт/сутки.

Из приведенных данных видно, что данные технические параметры может обеспечить термоэлектрический генератор мощностью 200 Вт, работающий совместно с электрическим аккумулятором, при этом будет обеспечен двукратный расчетный энергетический запас. Эксплуатация данной системы с термоэлектрическим генератором в течение зимнего сезона 20202021 гг. показало, что система функционирует исправно, нарушений в работе отсутствуют.

Проведенные литературные и экспериментальные исследования показали, что применение альтернативных источников энергии для реновации старого жилья является одним из перспективных научных направлений, которое может раскрыть большие возможности по увеличению качественных показателей административного и жилого фонда.

Исследование выполнено при финансовой поддержке РФФИ и Правительства Иркутской области в рамках научного проекта № 20-48380002. 


\section{Список литературы}

1. Электронный ресурс. Мировая реновация. https://moslenta.ru/ urbanistika/mirovaya-renovaciya.htm

2. Köysal Y., Özdemir A.E., Atalay T. Experimental and modeling study on solar system using linear fresnel lens and thermoelectric module Journal of Solar Energy Engineering, Transactions of the ASME. 2018. T. 140. № 6. С. 061003.

3. Фортов В.Е., Попель О.С. Возобновляемые источники энергии для энергоснабжения потребителей в России // Энергетический вестник. 2010. № 1 (8). С. $9-29$.

4. Соколов М.М. Использование возобновляемых и нетрадиционных источников энергии: учеб. пособие / М.М. Соколов; Нижегор. гос. архитектур. - строит. ун-т. - Н. Новгород: ННГАСУ, 2015. - 116 с.

5. Шелехов И.Ю., Смирнов Е.И., Рупосов В.Л., Шишелова Т.И. Опыт использования термоэлектрических генераторов. Журнал "Фундаментальные исследования".- 2013.-№ 11 (часть 5).- С. 919-923.

6. Шелехов И.Ю., Шишелова Т.И., Смирнов Е.И. Новые технические решения для проектирования Термоэлектрических систем. Вестник мордовского университета $=$ Бюллетень мордовского университета. 2018; 28(1): 48-61. DOI: 10.15507/0236-2910.028.201801.048-061 